\author{
Research Article
}

\title{
EFFECTIVENESS OF PANCHAVALKALA PRALEPA AND JALAUKAVACHARANA IN REDUCING DURATION FOR REGRESSION OF VRANASHOPHA W.S.R. TO CELLULITIS: A RANDOMIZED CONTROLLED TRIAL
}

\section{Jaybhaye.Geeta ${ }^{*}$, Badwe. Yogesh ${ }^{2}$}

*1PG Scholar, 2 Professor and HOD, Department of Shalyatantra, Shri Ayurved Mahavidyalaya, Nagpur, Maharashtra India.

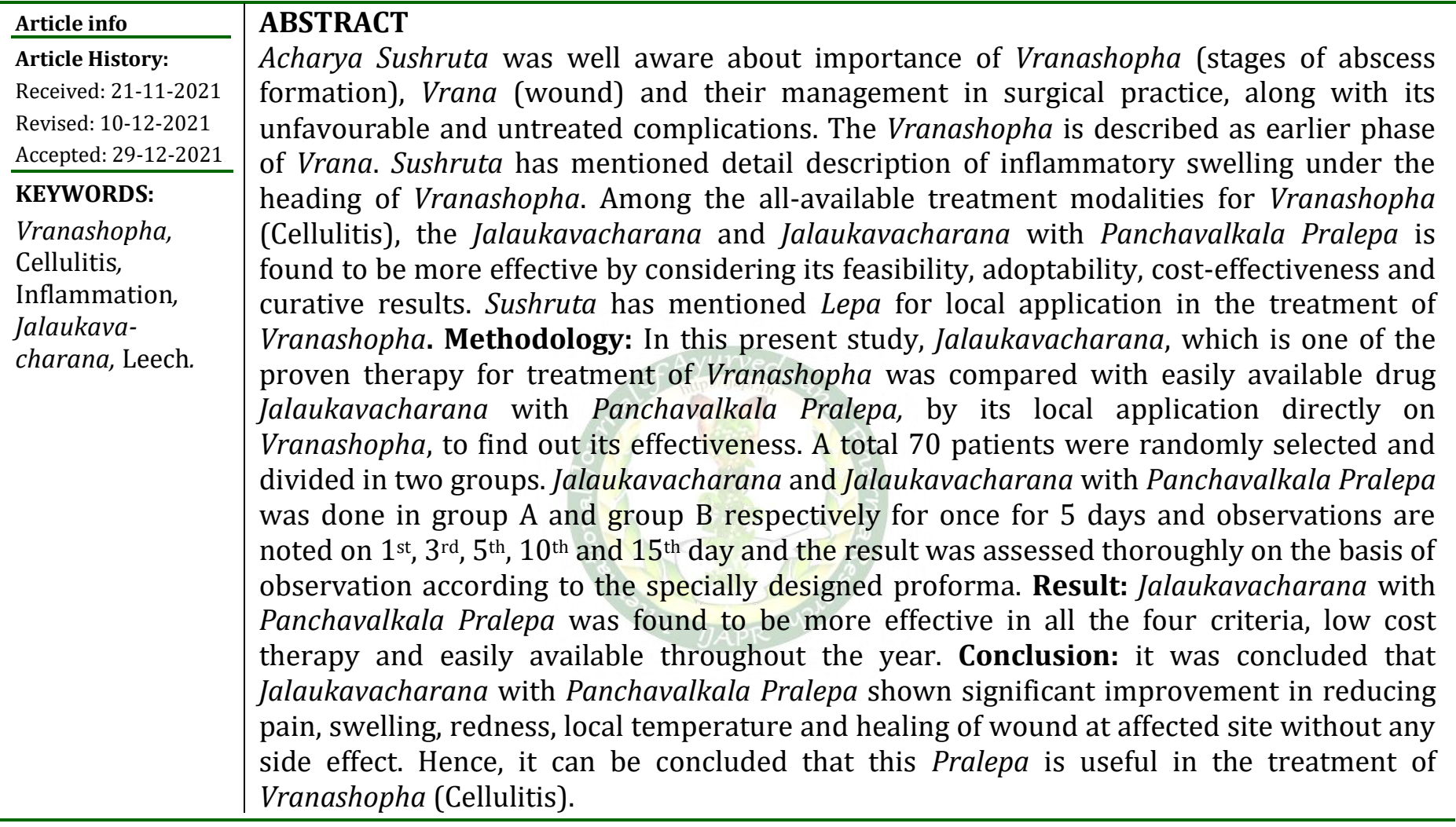

\section{INTRODUCTION}

Vranashopha and Vrana have been a topic of interest for the surgeons since ancient times. Vranashopha is the most encountered condition in Shalyatantra which has to be treated as early as possible to avoid further surgical intervention and complications. Vranashopha is the preliminary stage of Nija Vrana which is one of the most potential and attention seeking clinical condition in daily life.

\begin{tabular}{|l|l|}
\hline \multicolumn{3}{|c|}{ Access this article online } \\
\hline Quick Response Code & \\
\hline & $\begin{array}{l}\text { Pttps://doi.org/10.47070/ijapr.v10i1.2248 } \\
\text { Published by Mahadev Publications (Regd.) } \\
\text { Commons licensed under a Creative } \\
\text { ShareAlike 4.0 International (CC BY-NC-SA 4.0) }\end{array}$ \\
\hline
\end{tabular}

Sthanika Shopha is termed as Vranashopha which occupies a significant place in surgical practices ${ }^{[1]}$. Vranashopha is characterized by Ekdeshiya Shotha, Twakvivarnata, Osha, Chosha, Paridaha like Vedana[2]. There are three stages of any type of Vranashopha as Amavastha, Pachyamanavastha and Pakwavastha[3], which has mainly six types. The six types are as Vataja, Pittaja, Kaphaja, Sannipatika, Raktaja and Agantuja Vranashopha[ ${ }^{[4]}$. Sign and symptoms of Vranashopha are more or less similar to cellulitis ${ }^{[5]}$. Cellulitis is spreading type of inflammation of subcutaneous tissue generally associated with bacterial infection. The skin findings in cellulitis follow the classic signs of inflammation: dolor (pain), calor (heat), rubor (erythema) and tumor (swelling)[6]. The basic principle of Vranashopha management is to prevent onset of Pakwavastha[7]. For early recovery of 
Vranashopha, Sushruta has mentioned, stage wise treatment (Upakarma). In these Upakramas, primary eleven are described for Vranashopha[8]. The Upakramas like Pralepa and Vistravana are used commonly in Ama and Pachyamana Awastha among these treatment modalities ${ }^{[9]}$.

Jalaukavacharana is an ancient method mentioned in Ayurveda used for purification of the body by removing deeply seated toxins in the blood and pacifying vitiated Doshas ${ }^{[10]}$. It is indicated in acute condition to relieve pain and to prevent Paka[11]. Leech application i.e., Hirudotherapy bears antiinflammatory pharmacokinetics due to enzymes like Bdellins and Eglins in the saliva. So, it can be used in the treatment of Vranashopha[10]. Sushruta has explained Pralepa with numerous herbal drugs as Pradhanatama treatment of Vranashopha[12]. One of them is, Panchavalkala bear Kashayarasa and has Prakshalana, Shothahar, Vranaropana and Twakprasadana properties. It also possesses antibacterial property as well as anti-inflammatory effect[13]. Sushruta praised Lepa as it relieves pain as blazing house is readily extinguished by means of showering[14]. Above said properties of Panchavalkala can subside the Vranashopha. Chakradatta has also mentioned Panchavalkala Pralepa in the management of Vranashopha[15].

Need of Study: Cellulitis has been treated with antibiotic, analgesics and anti-inflammatory drug along with glycerin and magnesium sulphate dressing due to its hygroscopic property. Although using antibiotics and hygroscopic dressings the oedema and pain takes longer time to resolve cellulitis[10]. Application of Panchavalkala Pralepa rather than Glycerin-Magsulf dressing will be more beneficial to resolve inflammation in case of cellulitis as per the properties of Panchavalkala. Jalaukavacharana is an established therapy in treatment of Vranashopha. The anti-inflammatory effect of leech therapy was published in various articles same is in the case of Panchavalkala. It is observed that Jalaukavacharana and different Pralepa when used individually, it takes much time to resolve the inflammation. It is hypothetically assumed that by using both therapies

Assessment Criteria

\section{Subjective Criteria}

Vedana/Pain

Assessment criteria for pain by VAS

Assessment criteria for pain measurement by visual analog scale as follow:

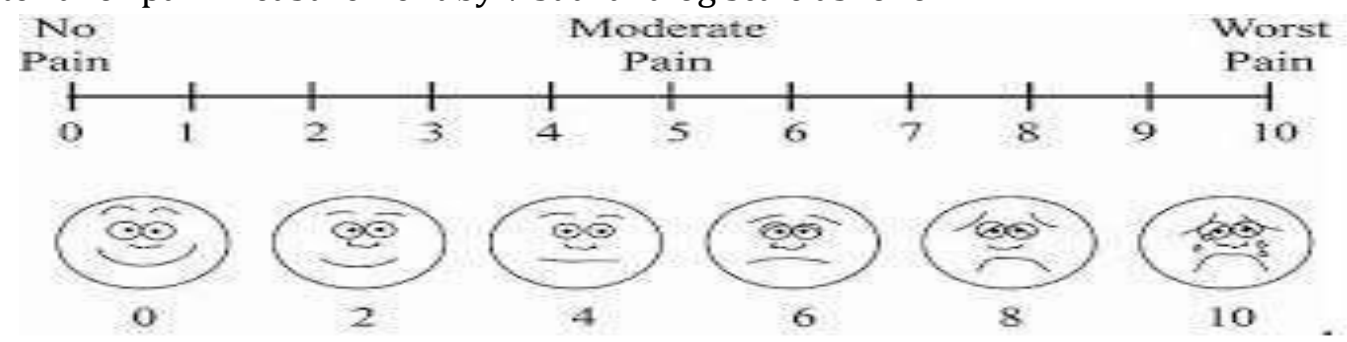


Table 1: Assessment criteria for Pain

\begin{tabular}{|l|l|l|l|l|}
\hline Sr. No. & Assessment Parameters & Rating Pain Level & Rating & Grade \\
\hline \multirow{3}{*}{$\mathbf{1}$} & \multirow{2}{*}{ Pain (as per Vas scale) } & No Pain & 0 & 0 \\
\cline { 3 - 5 } & & Mild Pain & $1-3$ & I \\
\cline { 3 - 5 } & & Moderate Pain & $4-6$ & II \\
\cline { 3 - 5 } & & Severe Pain & $7-10$ & III \\
\hline
\end{tabular}

\section{Objective Criteria}

1. Utsedh/ Swelling

2. Sthanik Ushma/ Local temperature

3. Twak Vivarnata / Redness

\section{Utsedh/Swelling}

\section{Assessment criteria of $U t s e d h / S w e l l i n g$}

Utsedh measured in centimeter by scale or measuring tape before and after treatment.

Assessment criteria for Sthanik Ushma/Local temperature

Local temperature will be measured by infra-red thermometer

Assessment Criteria for Redness

Table 2: Assessment criteria for Redness

\begin{tabular}{|l|l|l|c|}
\hline Sr.no & Criteria & Reduction in percentage & Grade \\
\hline \multirow{3}{*}{1.} & \multirow{2}{*}{ Redness } & No redness & 0 \\
\cline { 3 - 4 } & & Redness upto 25 \% & 1 \\
\cline { 3 - 4 } & & Redness upto 26-50 \% & 2 \\
\cline { 3 - 4 } & & Redness upto 51-75\% & 3 \\
\cline { 3 - 4 } & & Redness upto 76-100\% & 4 \\
\hline
\end{tabular}

Overall Assessment Criteria: Criteria of assessment was based on improvement in subjective and objective parameters after the treatment. The results were categorized as,

Complete relief -- $75 \%$ and above

Moderate relief -- $50 \%$ to $74 \%$ improvement

Mild relief -- 25 to $49 \%$ improvement

No relief -- Below 24\% improvement

\section{METHODS}

Fresh leeches, storage pot, purification trays, turmeric powder, rice, Saindhava salt, sterile needle, dressing materials.

1. Jalauka (Leech and Leech lab)

2. Haridra Churna

3. Sterilized Gauze pieces, dressing pad, cotton, gloves

4. Kidney tray, distilled water, needle

5. Container of sterile water, for placing leeches after they have been fed. These are the basic requirements for leech therapy

\section{Methodology of Jalaukavacharana (Leech Therapy) [16]: As Described by Sushrut acharya}

A) Purva karma- 2-3 Jalaukas (according to size of Vranashopha) of moderate size was first prepared for Raktamokshana by keeping it in Haridra Jala. Affected site cleaned by distilled water prior to leech therapy and then by dry gauze.

B) Pradhana karma - After wearing the latex gloves prepared active leeches were kept over the Vranashopha and its periphery. If needed, Vranashopha were punctured with sterilized needle and when blood oozes the leeches were kept on it.[17] When leech started to suck blood by itself, then wet cotton pad was placed over it. The process of blood sucking was confirmed by the peristalsis movements on the body of the leeches. When the leech completes blood sucking it detached itself from the bite site. 
C) Paschat karma- Haridra Churna was applied over the bite lesions and pressure dressing done. Haridra Churna was sprinkled over the leech's anterior sucker (mouth) for inducing vomiting. After expelling all the blood from its gut, the leech became active again and was stored in fresh water container.

\section{Methodology of Panchavalkala Pralepa}

\section{1) Purvakarma: Preparation of Panchavalkala Pralepa}

1. For each patient, the Pralepa will be made freshly.

2. Fine powder of Panchavalkala will be taken as per the requirement in bowl.

3. Warm Go-ghrita and distilled water will be added in Panchavalkala as per requirement and mixed well, fine paste for Pralepa will be made.

\section{2) Pradhankarma:}

1. The Panchavalkala pralepa will be applied locally on the Vranashopha once in a day in the morning. After Jalaukavacharana by avoiding the site of bite.

2. Pralepa of width approximately skinned skin of buffalo was applied against the direction of Romakupa i.e., Pratilomagati.

\section{3) Pashchatkarma}

1. Panchavalkala Pralepa will be removed when it will become dry with the help of cotton ball soaked in Luke warm water.

\section{RESULTS}

\section{Discussion on Effect of Therapy for Group A}

Pain: The initial mean score of pain observed was 5.60, which come down to 0.97 at $5^{\text {th }}$ day and 0.20 mean at $15^{\text {th }}$ day of treatment. At initial standard deviation was 1.22 which comes down to 1.12 at $5^{\text {th }}$ day and 0.28 at $15^{\text {th }}$ day. Change in effect from baseline up to $5^{\text {th }}$ day was $64.73 \%$ and up to $15^{\text {th }}$ day it was $97.58 \%$ that means significant relief in pain.

Redness- The initial mean score of redness observed was 3.00 which come down to 0.11 at $5^{\text {th }}$ day and 0.03 mean at $15^{\text {th }}$ day of treatment. At initial standard deviation was 0.00 which comes down to 0.32 at $5^{\text {th }}$ day and 0.00 at $15^{\text {th }}$ day. Change in effect from baseline up to $5^{\text {th }}$ day was $96.19 \%$ and up to $15^{\text {th }}$ day it was $99.00 \%$ that means significant relief in redness.

Swelling-The initial mean score of swelling observed was 28.39 which come down to 27.01 at $5^{\text {th }}$ day and 25.60 mean at $15^{\text {th }}$ day of treatment. At initial standard deviation was 3.90 which comes down to 3.72 at $5^{\text {th }}$ day and 5.71 at $15^{\text {th }}$ day. Change in effect from baseline up to 5 th day was $4.84 \%$ and up to 15 th day it was $9.81 \%$ that means significant relief in swelling.

Local Temperature- The initial mean score of local temperature observed was 99.69 which come down to 98.04 at $5^{\text {th }}$ day and 97.51 mean at $15^{\text {th }}$ day of treatment. At initial standard deviation was 0.58 which comes down to 0.22 at $5^{\text {th }}$ day and 0.44 at $15^{\text {th }}$ day. Change in effect from baseline up to 5 th day was $1.65 \%$ and up to 15 th day it was $2.19 \%$ that means significant relief in local temperature.

\section{Discussion on Effect of therapy for Group B}

Pain: The initial mean score of pain observed was 5.91 which come down to 2.09 at $5^{\text {th }}$ day and 0.14 mean at $15^{\text {th }}$ day of treatment. At initial standard deviation was 0.74 which comes down to 1.12 at $5^{\text {th }}$ day and 0.36 at $15^{\text {th }}$ day. Change in effect from baseline up to 5 th day was $64.73 \%$ and up to 15 th day it was $97.58 \%$ that means significant relief in pain.

Redness- The initial mean score of redness observed was 3.00 which come down to 0.46 at $5^{\text {th }}$ day and 0.00 mean at $15^{\text {th }}$ day of treatment. At initial standard deviation was 0.00 which comes down to 0.51 at $5^{\text {th }}$ day and 0.00 at $15^{\text {th }}$ day. Change in effect from baseline up to 5 th day was $84.76 \%$ and up to 15 th day it was $100 \%$ that means significant relief in redness.

Swelling- The initial mean score of swelling observed was 27.74 which come down to 26.37 at $5^{\text {th }}$ day and 24.93 mean at $15^{\text {th }}$ day of treatment. At initial standard deviation was 5.71 which comes down to 5.72 at $5^{\text {th }}$ day and 5.73 at $15^{\text {th }}$ day. Change in effect from baseline up to 5 th day was $4.94 \%$ and up to 15 th day it was $4.94 \%$ that means significant relief in swelling.

Local Temperature- The initial mean score of local temperature observed was 99.83 which come down to 98.21 at $5^{\text {th }}$ day and 97.52 mean at $15^{\text {th }}$ day of treatment. At initial standard deviation was 0.50 which comes down to 0.27 at $5^{\text {th }}$ day and 0.37 at $15^{\text {th }}$ day. Change in effect from baseline up to 5 th day was $1.63 \%$ and up to 15 th day it was $2.32 \%$ that means significant relief in local temperature. 
Table 3: Comparison of change in all parameter of two groups

\begin{tabular}{|l|l|c|c|c|c|c|c|}
\hline \multicolumn{1}{|c|}{ Days Required } & Group & N & Mean & SD & SE & Z- Value & P-Value \\
\hline \multirow{2}{*}{ Pain } & Group A & 35 & 9.17 & 2.86 & 0.48 & \multirow{2}{*}{-3.163} & \multirow{2}{*}{0.002338} \\
\cline { 2 - 6 } & Group B & 35 & 6.86 & 3.25 & 0.55 & & \\
\hline \multirow{2}{*}{ Swelling } & Group A & 35 & 11.89 & 2.52 & 0.43 & \multirow{2}{*}{-2.440} & \multirow{2}{*}{0.017278} \\
\cline { 2 - 7 } & Group B & 35 & 7.50 & 2.51 & 0.42 & & \\
\hline \multirow{2}{*}{ Local Temperature } & Group A & 35 & 7.80 & 0.94 & 0.16 & \multirow{2}{*}{-4.227} & \multirow{2}{*}{0.000072} \\
\cline { 2 - 6 } & Group B & 35 & 4.26 & 0.98 & 0.17 & & \\
\hline \multirow{2}{*}{ Redness } & Group A & 35 & 7.20 & 0.97 & 0.16 & \multirow{2}{*}{-4.661} & \multirow{2}{*}{0.000015} \\
\cline { 2 - 6 } & Group B & 35 & 4.26 & 0.98 & 0.17 & & \\
\hline
\end{tabular}

We have used Z-test for comparison between Group A and Group B. From above table we can observe that P-Value is less than 0.05 . Hence we can conclude that, there is significant difference between Group A and Group B.

Further we can observe that, mean value of number of days required for Group B is less than Group A. Hence we can conclude that, effect observed in Group B is better than Group A.

Table 4: Average number of days required in both group

\begin{tabular}{|c|c|}
\hline Group & Average No of Days Required \\
\hline Group A & 9.02 \\
\hline Group B & 5.72 \\
\hline
\end{tabular}

Graph no.1: Percentage of relief in 4 parameters.

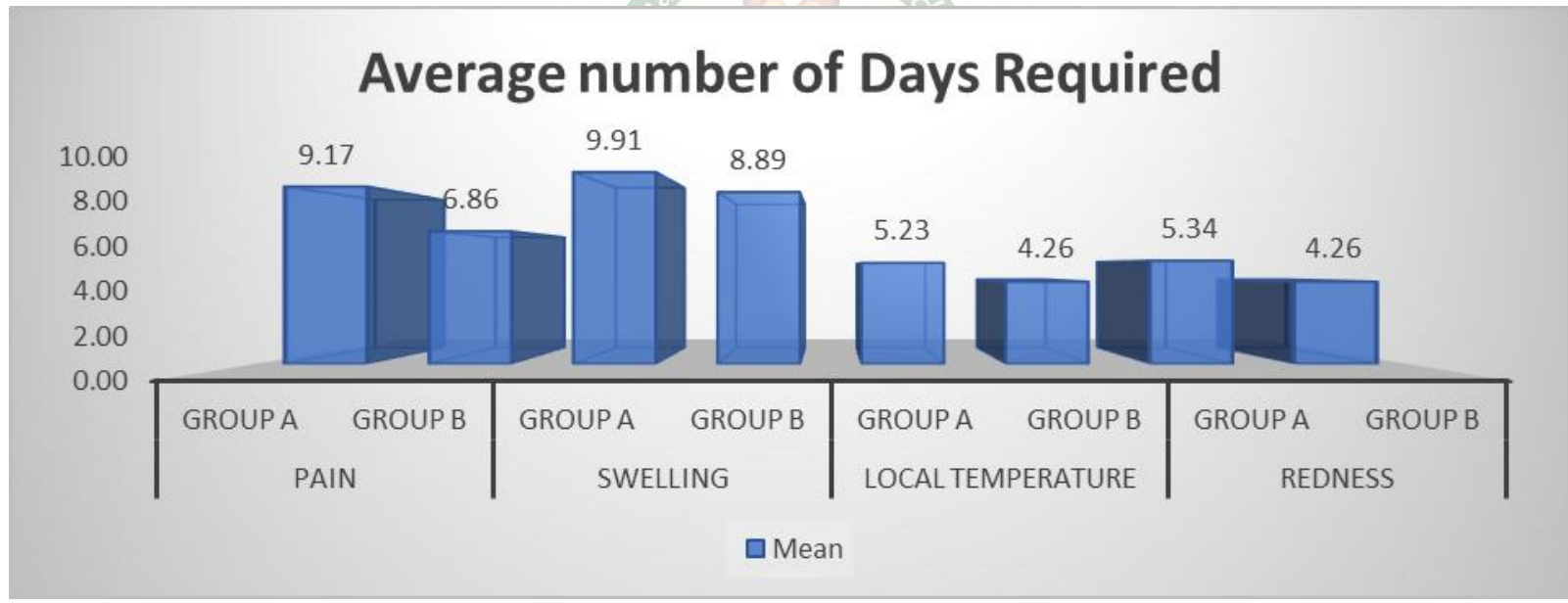

\section{Images of Patients}

1) Control group (group A): Jalaukavacharana

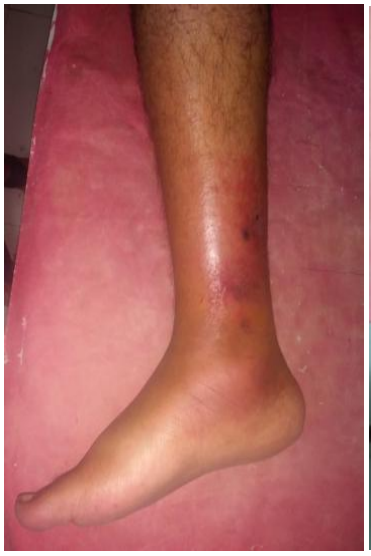

Before

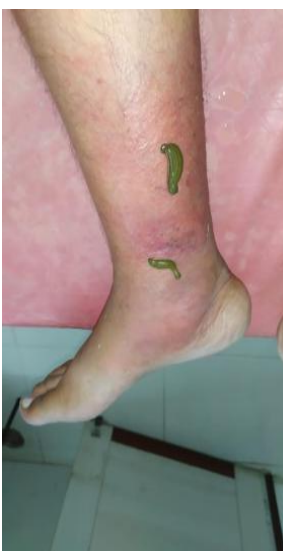

During

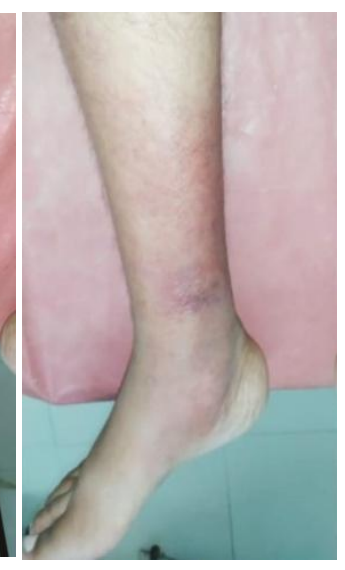

After 


\section{2) Trial group (Group B): Jalaukavacharana with Panchavalkala Pralepa}

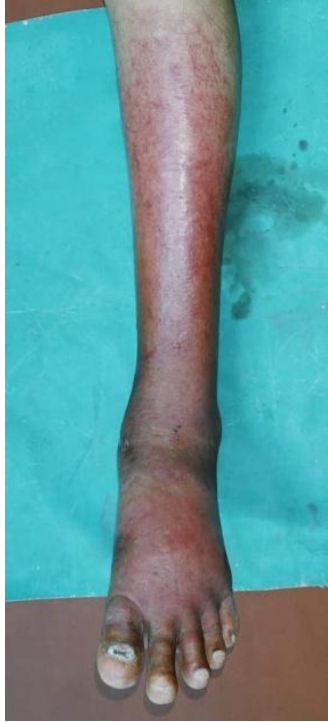

Before

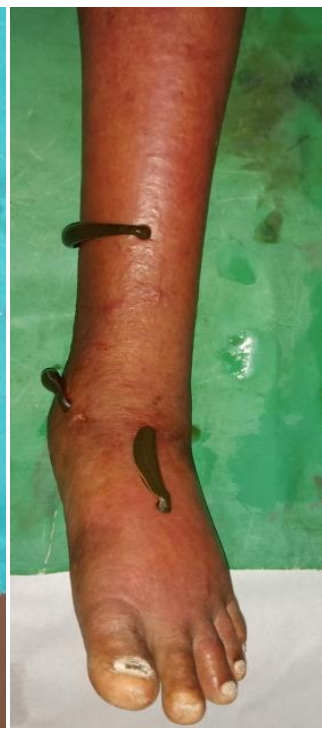

During

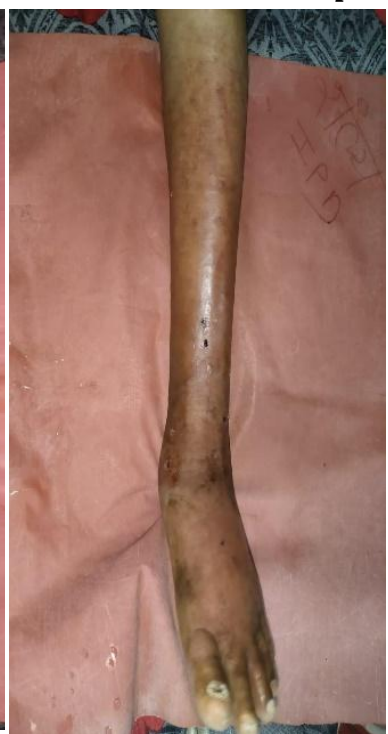

After
Discussion on Comparison of Result in Both Groups

In this study Jalaukavacharana was compared with Jalaukavacharana with Panchavalkala Pralepa as it is abundantly and easily available treatment for Vranashopha. There is no need to state that modern medical treatment has its own limitation in managing this type of disease. This suggests special need of an Ayurvedic management for this type of conditions. As the number of patients suffering from this disease are increasing day by day. Ayurvedic physician should also make effort continuously to find out effective remedy for the patients of Vranashopha from Ayurvedic classics. To achieve good results and early reduction in signs and symptoms of Vranashopha, Acharya Sushruta has explained Shashti Upakramas (sixty types of treatment procedures) in Dwivraniya Adhyaya of Chikitsasthana for comprehensive management of Vrana out of them first eleven (Apatarpana to Virechana) is described for treatment of Vranashopha. Acharya Sushruta also mentioned Shodhana by Raktamokshana (bloodletting) in acute inflammatory conditions, indurate, cyanosed, painful swellings and many inflammatory conditions like Vidhradhi, Granthi, Arbuda etc. It contains various bioactive constituent which possesses anti-inflammatory, analgesic, thrombolytic, antioxidant, vasodilator, anti-coagulant and blood circulation enhancing properties and advised Jalaukavacharana (Leech therapy) in Vranashopha (Cellulitis) ${ }^{[18] .}$

Sushruta has explained Pralepa with numerous herbal drugs as Pradhantama treatment of Vranashopha [19]. Panchavalkala have bark of 5 dravyas i.e., Ashwattha, Vat, Udumbar, Plaksha and Parisha has Kashayarasa and Prakshalana, Shothahara, Vranaropana and Twakprasadana properties. It also possesses antibacterial property as well as antiinflammatory effect. Pralepa itself bears Rakta- prasadana and Shothahara properties ${ }^{[13]}$. Chakradatta explained Panchavalkala Pralepa for treatment of Vranashopha. it reduces all the inflammatory sign and symptoms of Vranashopha. ${ }^{[20]}$

\section{Average Number of Days Required for Both Group}

For Group A it was about 9 days and for group B it was about 5 to 6 days for regression of overall symptoms of Vranashopha.

Overall Result of Therapy- Among 70 patients, overall effect of therapy as, Group A: 20 (57.14\%) patients were markedly improved while 15 (42.86\%) patients moderately improved.

Group B: 33 (94.29\%) patients were markedly improved while $2(5.71 \%)$ patients moderately improved.

No cases noticed mild improved and unchanged in both groups. By the observations and more effect of group B (trial group), we can say that this add on effect is due to Panchavalkala Pralepa.

\section{CONCLUSION}

1. Time required for the regression of overall symptoms of Vranashopha in Jalaukavacharana with Panchavalkala Pralepa was about 5 to 6 days and only Jalaukavacharana was about 9 days was found statistically significant.

2. Panchavalkala Pralepa with Jalaukavacharana in the patients of Vranashopha w. s. r. to Cellulitis was found early effective.

3. Remission of symptoms like pain, redness, swelling and local temperature was found in the treatment of Jalaukavacharana with Panchavalkala Pralepa than Jalaukavacharana only.

4. During the whole study, we found that there was no adverse reaction of Jalaukavacharana and Panchavalkala Pralepa. Hence the therapy is safe. 


\section{REFERENCES}

1. Dr Asutkar Sheetal G, A conceptual overview on inflammatory markers in patients of cellulitis (Vranashopha) and its management with leech therapy. January 2016; Pg no 16.

2. Sushruta. Sushruta-Samhita, Ayurved Tattva Sandipika, Dr.Kaviraja Ambikadatta shastri. Sutrasthana-17/8, edition reprint 2016, chaukhambha Sanskrit Santhana Varanasi: 93.

3. Sushruta; Sushruta-Samhita; nibandha sangraha commentary of Shri dalhana charya; reprint edition, edited by Yadavaji trikamji acharya, Varanasi; Chaukhambha orientalia publishers; 2003; pp 824, pg no 82, (su, su 17/5).

4. Sushruta. Sushruta-Samhita, Ayurved Tattva Sandipika, Dr.Kaviraja Ambikadatta shastri. Sutrasthana- 17/4, edition reprint 2016, Chaukhambha Sanskrit Santhana Varanasi; 92.

5. Dr. Anil K. Tripathi et al, Haematological Study In Patients Of Cellulitis Treated By Leech Therapy, J. Res. Educ. Indian Med., Vol. XVII (3-4): 95- 100 (2011).

6. Adam B. Raff-Cellulitis a Review, JAMA. 2016 Jul 19;316(3):325-37.

7. Sushruta; Sushruta-Samhita; nibandha sangraha commentary of Shri dalhana charya; reprint edition, edited by Yadavaji trikamji acharya, Varanasi; Chaukhambha orientalia publishers; 2003; pp 824, pg no83, su, su 17/10-12.

8. Sushruta. Sushruta-Samhita Chikitsasthana, Ayurved Tattva Sandipika, Dr.Kaviraja Ambikadatta shastri. Chikitsa sthana-1/10, edition reprint 2015, Chaukhambha Sanskrit santhan, Varanasi; 2015: pg no 6.

9. Sushruta; Sushruta-Samhita; nibandha sangraha commentary of Shri dalhana charya; reprint edition, edited by Yadavaji trikamji acharya, Varanasi; Chaukhambha orientalia publishers; 2003; pp 824, pg no84, su, su 17/17.

10. Dr Asutkar Sheetal G, Yogesh Badwe, Balika Bhatbhage. Pain management and wound bed preparation of a chronic non healing wound over heel by Leech Therapy- A case Study. URIM June 2018; 7(2): 2456- 4435.
11. Dr Yogesh R Badwe, Amit A Paliwal and Vasudha Asutkar. Managament of Vranashopha by Punarnavadi Lepa and Jalaukavacharana - A Comparative Clinical Study. AJMS 2018; Pg no 1(7).

12. Sushruta. Sushruta-Samhita Sutrasthana, Ayurved Tattva Sandipika Dr. Kaviraja Ambikadatta shastri. Sutrasthana-18/3, edition reprint 2015, Chaukhambha Sanskrit Santhana, Varanasi: 96.

13. Dravyaguna-Vigyan, V. Ayurveda Granthmala. Acharya Priyavat Sharma, Mishrak Adhyaya10, reprint 6th, V.sanvat 2036, Chaukhambha Bharati Academy; pg. no. 118.

14. Sushruta. Sushruta-Samhita, Ayurved Tattva Sandipika Dr.Kaviraja Ambikadatta shastri. Chikitsasthana-1/15, edition reprint 2015, Chaukhambha Sanskrit Santhan Varanasi; 2015: 6.

15. Chakradatta. Chakrapanivirchit, Chakradatta Bhavarthsandeepini Shri Jagdeeshwar prasad Tripathi. Chikitsasthana-44/5, edition reprint 2040, chaukhambha Sanskrit series office Varanasi: 2040: 345.

16. Dr. P. Sreenivasa. Comparison between dressing of cellulitis with normal saline and Magnessium Sulphate. http://www.ijsurgery.com, 5(4).

17. Asutkar Sheetal, Balika Bhatbhage. A Conceptual Study of Wound Bed Preparation by Leech therapy (Jalaukavacharana) In Patients of Dushta Vrana w.s.r. Chronic Non-Healing Wound.IJ-RIM. 0ct Dec2018; 2(6); 1-14.

18. Shastri Ambika Dutta, Sushrut Samhita Sutra Sthana, Jalaukavacharaniya adhyaya. Hindi Commentary. 14th Edition. Varanasi. Chaukambha Sanskrit Sansthan; vol-1, 2003. p.43.

19. Sushruta. Sushruta-Samhita Sutrasthana, Ayurved Tattva Sandipika Dr. Kaviraja Ambikadatta shastri. Sutrasthana-18/3, edition reprint 2015, Chaukhambha Sanskrit Santhana, Varanasi; 2015: 96.

20. Chakradatta. Chakrapanivirchit Chakradatta, Bhavarthsandeepini Shri Jagdeeshwarprasad Tripathi. Chikitsasthana-44/5, edition reprint 2040, chaukhambha Sanskrit series office Varanasi: 2040:345.

\section{Cite this article as:}

Jaybhaye.Geeta, Badwe. Yogesh. Effectiveness of Panchavalkala Pralepa and Jalaukavacharana in Reducing Duration for Regression of Vranashopha w.s.r. to Cellulitis: A Randomized Controlled Trial. International Journal of Ayurveda and Pharma Research. 2022;10(1):21-27.

https://doi.org/10.47070/ijapr.v10i1.2248

\section{Source of support: Nil, Conflict of interest: None Declared}

\section{*Address for correspondence} Dr. Geeta Baban Jaybhaye

PG Scholar,

Department of Shalyatantra, Shri Ayurved Mahavidyalaya, Nagpur, Maharashtra India. Email: jaybhayegeet093@gmail.com Mob: 9765436371

Disclaimer: IJAPR is solely owned by Mahadev Publications - dedicated to publish quality research, while every effort has been taken to verify the accuracy of the content published in our Journal. IJAPR cannot accept any responsibility or liability for the articles content which are published. The views expressed in articles by our contributing authors are not necessarily those of IJAPR editor or editorial board members. 